\title{
Comparison between Deciduous and Permanent Incisor Teeth in Morphology of Bovine Enamel
}

\author{
By
Iwao SATO, Masataka SUNOHARA, Akiko MIKAMI, Shunji YOSHIDA and Toru SATO

Department of Anatomy, School of Dentistry at Tokyo, the Nippon Dental University, Tokyo, 102-8159 Japan

- Received for Publication, February 19, $1999-$

\begin{abstract}
Key Words: Bovine, Enamel, Prism, Ultrastructure
Summary: Functional incisor teeth (deciduous and permanent teeth) from Bovidae (14 species) were prepared for scanning electron microscopic observation. Ultrastructural patterns of the enamel layer of deciduous and permanent incisor teeth varied (ex. prisms, arrangement pattern of matrices, and in thickness of enamel layer) in each species. The ultrastructures of prisms in longitudinal sections were classified into three types; $\mathbf{A}$, radial, B, tangential, and $\mathbf{C}$, mix of $A$ and $B$ arrangement enamel; modified Koenigswald's method (1982) in examined species. Type $A$ was found in a large part of permanent and a small part of deciduous incisor teeth, while types $B$ and $C$ were mainly found in the deciduous teeth.
\end{abstract}

These morphological features show the remarkable correlation between permanent and deciduous teeth.

The ultrastructural patterns of prisms in cross sections in Insectivora, Chiroptra, Sirenia, Cetacea, Equidae, Primates (Bode and Martin, 1982, 1984; Bode et al., 1978; Warshawsky et al., 1981), Rodents (Boyde, 1978; Koenigswald, 1982), and also Multituberculates (fossil mammal) (Carlson and Krause, 1985) have been classified into A, radial, B, tangential, and $\mathrm{C}$, mix of $\mathrm{A}$ and $\mathrm{B}$ arrangement enamel. In longitudinal section of the teeth, prisms showed three patterns (Boyde, 1964, 1976); even though very few species were examined. The morphological feature of prism in Rodent teeth indicate the functional profiles (Koenigswald, 1982). Koenigswald and Pfretzschner (1987) suggest morphological features are related to function. Therefore, the arrangement of prisms may indicate the biting ability of teeth.

This study describes the arrangement patterns of prisms in the enamel layer of the deciduous and permanent teeth of Bovidae species. The results of examined the morphology between deciduous and permanent incisor teeth demonstrate the functional properties of occlusal system.

\section{Materials and Methods}

We examined a total of 14 species of Bovidae teeth (Table 1). All the skeletons that provided teeth for this study were prepared for dried carcasses dermestid beetles, and cleaned with a brief exposure to commercial laundry bleach, followed by ten minutes in $95 \%$ ethanol. Some pieces (5$6 \mathrm{~mm}^{2}$ ) of teeth and other whole teeth were cut at ground tangenital to the tooth surface and sectioned (about $2 \mathrm{~mm}$ thick) with a diamond disc. These materials were fixed for 30 minutes in $10 \%$ paraformaline solution, then dehydrated in acetone and finally embedded in epoxy resin (Epon-812). Some sections were etched with $0.1 \mathrm{~N} \mathrm{HCl}$ for $15-$ 16 sec., dehydrated in ethyl alcohol and then dried by a critical point drying method (Horridge and Tamm, 1969). They were coated with a $1.5-\mathrm{nm}$ gold-palladium layer and observed under a Hitachi $\mathrm{X}-560$ scanning electron microscope (SEM).

\section{Result}

The enamel layers in the examined teeth vary

Correspondence to Dr. Iwao Sato, Ph.D. Department of Anatomy, the Nippon Dental University, School of Dentistry at Tokvo. 1-9-20, Fujimi, Chiyoda-ku, Tokyo 102-8159, Japan. 
Table 1. Tabulation of the bovidae taxa and specimens examined in this study

\begin{tabular}{|c|c|c|c|c|c|}
\hline Classification & Species & Examined & Specimens & Age & Sex \\
\hline \multicolumn{6}{|c|}{$\begin{array}{l}\text { Order Artiodactyla } \\
\text { Family Bovidae }\end{array}$} \\
\hline & Tragelaphus & s. $\quad$ strepsiceros & $\mathrm{LI}_{1}(\mathrm{~S}-372)^{*}$ & 1D & $\mathrm{Ma}$ \\
\hline & Bos & $\begin{array}{r}\text { strepsiceros } \\
\text { juvanicus }\end{array}$ & $\mathrm{RI}_{3}(\mathrm{~S}-353)$ & Inf. & $\mathrm{Ma}$ \\
\hline & Oryx & $\begin{array}{r}\text { juvanicus } \\
\text { gazella callotis }\end{array}$ & $\mathrm{RI}_{1}(\mathrm{~S}-352)$ & Inf. & $\mathrm{F}$ \\
\hline & gazella & $\begin{aligned} \text { gazella callotis } & \text { callotis }\end{aligned}$ & $\mathrm{RI}_{1}(\mathrm{~S}-359)$ & $1 \mathrm{D}$ & $\mathrm{Ma}$ \\
\hline & Addax & & $\mathrm{RI}_{1}(\mathrm{~S}-213)$ & Inf. & \\
\hline & Damaliscus & $\begin{array}{l}\text { nasomaculanus } \\
\text { lunatus topi }\end{array}$ & $\mathrm{LI}_{1}(\mathrm{~S}-349)$ & 2M15D & $\mathrm{F}$ \\
\hline & Madoqua & k. $\quad k i r k i$ & $\mathrm{RI}_{1}(\mathrm{~S}-375)$ & Mat. & Ma \\
\hline & \multirow[t]{4}{*}{ Gazella } & granti roosevelti & $\mathrm{RI}_{1}(\mathrm{~S}-166)$ & Mat. & $\mathrm{F}$ \\
\hline & & dama mhorr & $\mathrm{LI}_{1}(\mathrm{~S}-433)$ & $3 \mathrm{D}$ & $\mathrm{F}$ \\
\hline & & mhorr & $\mathrm{LI}_{1}(\mathrm{~S}-509)$ & $7 D$ & $\mathrm{~F}$ \\
\hline & & mhorr & $\mathrm{LI}_{1}(\mathrm{~S}-394)$ & $42 \mathrm{D}$ & $\mathrm{F}$ \\
\hline & \multirow{3}{*}{$\begin{array}{l}\text { Saiga } \\
\text { Capra }\end{array}$} & t. $\quad$ tatarica & $\mathrm{RI}_{3}(\mathrm{~S}-535)$ & $7 Y$ & $\mathrm{~F}$ \\
\hline & & \multirow{2}{*}{$\begin{array}{l}\text { aegagrus cretica } \\
\text { ibex sibirica }\end{array}$} & $\mathrm{LI}_{3}(\mathrm{~S}-261)$ & Mat. & Ma \\
\hline & & & $\mathrm{LI}_{2}(\mathrm{~S}-532)$ & $5 \mathrm{Y} 11 \mathrm{M}$ & $\mathrm{F}$ \\
\hline & Ovis & orentalis gmelivi & $\mathrm{RI}_{3}(\mathrm{~S}-566)$ & $9 Y 5 \mathrm{M}$ & $\mathrm{F}$ \\
\hline & Pantholops & o. ourebia & $\mathrm{RI}_{1}(\mathrm{~S}-339)$ & Mat. & \\
\hline
\end{tabular}

Abbreviation: D, day; F, female; Inf., infant; M, month; Ma, male; Mat, adult; Y, year.

* San Diego State University.

from $100-200 \mu \mathrm{m}$ in thickness (Table 2) and are clearly separated from dentine layer (Fig. 1). The average enamel layer of permanent teeth (about $200-2,700 \mu \mathrm{m})$ is thicker than that of deciduous teeth (about $31-500 \mu \mathrm{m}$ ). Hunter-Schreger bands are found in most permanent teeth (Table 2).

Scanning electron microscopy shows that prisms are arranged regularly with many crystals closely packed together in different manners: $A$, radial enamel (Fig. 1a-b); B, tangential enamel (Fig. 1c-d); $C$, mix of $A$ and $B$ arrangement enamel (Fig. 1e-f). The interprismatic enamel is composed of many fine crystals and is found in each rod sheath. Enamel matrices have many small calcified masses (Fig. 1b, d, f). The prisms in deciduous incisor teeth are classified into various types of arrangements

Table 2. Tabulation of the enamel arrangement pattern and enamel thickness in this study

\begin{tabular}{|c|c|c|c|c|}
\hline \multicolumn{2}{|c|}{ Examined Species } & Arrangement & Enamel $(\mu \mathrm{m})$ & $\mathrm{HSB}^{* 3}$ \\
\hline \multicolumn{5}{|c|}{ Permanent Teeth } \\
\hline \multirow[t]{2}{*}{ Capra } & aegagrus cretica & B & 215 & $++^{* 4}$ \\
\hline & ibex sibirica & A & 700 & $+* 5$ \\
\hline Madoqua & k. $\quad k i r k i$ & $\mathrm{C}$ & 185 & ++ \\
\hline Gazella & granti roosevelti & B & 555 & ++ \\
\hline Saiga & t. $\quad$ tatarica & B & 525 & ++ \\
\hline Ovis & orentalis gmelivi & B & 860 & ++ \\
\hline Pantholops & o. ourebia & $\mathrm{B}$ & 2,688 & ++ \\
\hline \multicolumn{5}{|l|}{ Milk Teeth } \\
\hline Tragelaphus & s. strepsiceros & $\mathrm{C}$ & 208 & ++ \\
\hline & juvanicus & A & 350 & + \\
\hline \multirow[t]{2}{*}{ Oryx } & gazella callotis (S-352) & B & 517 & ++ \\
\hline & gazella callotis (S-359) & A & 350 & + \\
\hline Damaliscus & lunatus topi & A & 373 & + \\
\hline \multirow[t]{3}{*}{ Gazella } & dama mhorr (S-433) & $\mathrm{C}$ & 290 & ++ \\
\hline & dama mhorr (S-509) & A & 314 & + \\
\hline & dama mhorr (S-394) & $\mathrm{C}$ & 31 & $-* 6$ \\
\hline Addax & nasomaculanus & B & 390 & ++ \\
\hline
\end{tabular}

${ }^{* 1}$, see Table $1 ;{ }^{* 2}$, maximum thickness of enamel layer; ${ }^{* 3}$, Hunter-Scherger band; ${ }^{* 4}$, very developted HSB;

${ }^{* 5}$, developted HSB; ${ }^{* 6}$, non-HSB. 
prisms; S-349, S-353, S-359, and S-509 are classified as type A; S-213 and S-352 are classified as type B; S-372, S-394, and S-433 are classified as type C. In contrast, the prisms in permanent incisor teeth are mainly classified as type B except for S-532 (type A) and S-375 (Type C).

\section{Discussion}

Boyde $(1964,1976)$ reported three patterns of prisms in cross-sectional observation of mammal teeth. There are different arrangements of prisms between deciduous and permanent incisor teeth in our examined species. Our examined species are classified into three types of the prisms in longitudinal section. Type B resembles to the classification by Boyde (1964, 1976). However, since there are previous reports about classification in prisms in term of the evolution connected with fossils (Pfretzschner, 1993) or living species (Boyde and Martin, 1982, 1984; Boyde et al., 1978; Warshawsky et al., 1981; Boyde, 1978; Koenigswald, 1982), we tried to investigate to functional levels in biting ability of the tooth. For example, the arrangement of prisms in mammalian teeth has a specific structure called "the Hunter-Schreger bands" which indicates the load of chewing pressure (Kawai, 1955). Pfretzschner (1986) suggested that the structural adaptation is in response the stress factor in enamel varying loading condition. The higher tensile strength of fibers is the key to structural reinforcement of the material (Koenigaswald and Pfretzschner, 1991). Rensberger and Pfretzschner (1992) also suggested the specific microstructure of the canine enamel in Astrapotheres has resisted cracking under varied loading conditions. Therefore the Hunter-Schreger band reveals the ability in chewing pressure on the surface of enamel. In our examined species, the Hunter-Schreger band is always found in the enamel layer of permanent teeth except for Type C (S-394). A clearly defined Hunter-Schreger band is found mainly in type B. These morphological features has to reflect the load of chewing system in permanent teeth. Moreover, the enamel layer of the examined deciduous teeth has wide interprismatic enamel compared with permanent teeth, and deciduous teeth are mainly classified as type A. Type A is that where the enamel layer is composed of a wide interprismatic enamel and small prisms. Deciduous teeth are more likely to crack under chewing pressure than permanent teeth. Therefore specific morphological observations at ultrastrucual levels of enamel indicate the functional profiles between deciduous and permanent teeth.

\section{Acknowledgment}

Dr. David J. Archibald (Department of Biology, College of Sciences, San Diego State university, San Diego, California, 92182-0057, U.S.A.)

\section{References}

1) Boyde A. The structure and development of mammalian enamel. Ph.D. Thesis, University of London (For extensive enamel bibliography), 1964.

2) Boyde A. Enamel structure and cavity margins. Operative Dentistry 1976; 1:13-28.

3) Boyde A. Development of the structure of the enamel of the incisor teeth in the three classical subordinal groups of the Rodentia. In Butler PM and Joysey KA (eds): Development, function and evolution of teeth. pp 44-58, Academic Press, New York, 1978.

4) Boyde A, Jones SJ and Reynoids PS. Quantitive and qualitative studies of enamel etching with acid and EDTA. Scanning electron microscopy 1978; 11:911-1002.

5) Boyde A and Martin L. Enamel microstructure determination in hominoid and cercopithecoid primates. Anat Enbryol 1982; 165:193-212.

6) Bode A and Martin L. A non destructive survey of prism packing patterns in primate enamels. In Fearnhead RW and Suga S (eds): Tooth Enamel IV. pp 417-421, Elsevier, Amsterdam, 1984.

7) Carlson SJ and Krause DW. Enamel ultrastructure of multituberculate mammals; an investigation of variability. Contrib Mus Paleont Univ Mich 1985; 27:1-50.

8) Horridge GA and Tamm SL. Critical point drying for electron microscopic study of ciliary motion Science 1969; 163:817-818.

9) Kawai N. Comparative anatomy of the bands of schreger. Okajimas Folia Anat Jap 1955; 27:115-131.

10) Koenigswald Wv. Enamel structure in the molars of Arvicolidae (Rondentia, Mammalia), a key to functionalmorphology and phylogeny. In Kurten B (ed): Teeth: form, function, and evolution. pp 109-122, Columbia University Press, New York, 1982.

11) Koenigswald $W v$ and Pfretzschner HU. Hunter-SchregerBänder in Zahnschmelz von Säugetieren (Mammalia). Zoomorphology 1987; 106:329-338.

12) Koenigaswald $W v$ and Pferetzschner HU. Biomechanics in the enamel of mammalian teeth. In Schmidt-Kitter $\mathbf{N}$ and Vogel K (ed): Constructional Morphology and Biomechanics. pp 113-125, Springer-Verlag, Berlin, 1991.

13) Pfretzschner HU. Structural reinforcement and crack propagation in enamel. In Russell DE, Santoro J-P and Sigogneau-Russell D (eds): Teeth Revisited: Proceeding of the VIIth International Symposium on Dental Morphology, Paris, Mém Mus natn Hist nat Pars (série C) 1988; 53:133143.

14) Pfretzschner HU. Enamel microstructure and hypsodonty in large mammals. In Smith P (ed): Structure, function and evolution of teeth. pp 147-162, Freund Publishing House. London, 1992.

15) Pfretzschner HU. Enamel microstructure in the phylogeny of the equidae. J Vert Paleontol 1993: 13:342-349.

16) Rensberger JM and Pfretzschner HU. Enamel structure in astrapotheres and its functional implications. Scanning Microscopy 1992; 6:495-510.

17) Warshawsky H, Josephsen K, Thylstrup A and Fejerskov $O$. The development of enamel structure in rat incisors as 


\section{Explanation of Figures}

\section{Plate I}

Fig. 1. SEM photographs of tooth in Bovidae. Variation in enamel ultrastructural patterns.

Type A; (a) View of enamel layer in longitudinal section of tooth in Damaliscus lunatus topi. Prisms are parallel each other and are separated by interprismatic enamel, and orient at right angle to the tooth surface near the outer enamel layer (bar $=10 \mu \mathrm{m}$ ). (b) Enlargement of region of Fig. 1a $($ bar $=5 \mu \mathrm{m})$. Type B, (c) View of enamel layer in longitudinal section of tooth in Addax nasomaculatus. Prisms cross each other at about right angles. They have less interprismatic enamel (bar $=10 \mu \mathrm{m})$. (d) Enlargement of region of Fig. 1c $(\mathrm{bar}=2 \mu \mathrm{m})$. Type C; (e) View of enamel layer longitudinal sections of tooth in Tragelaphus s. strepsiceros. Two patterns, type A and B are partially mixed. (bar $=10 \mu \mathrm{m})$. (f) Enlargement of region of Fig. 1e (bar $=2 \mu \mathrm{m})$.

IP: interprismatic enamel, P: prism 
Bovine Tooth Enamel 135

Plate I

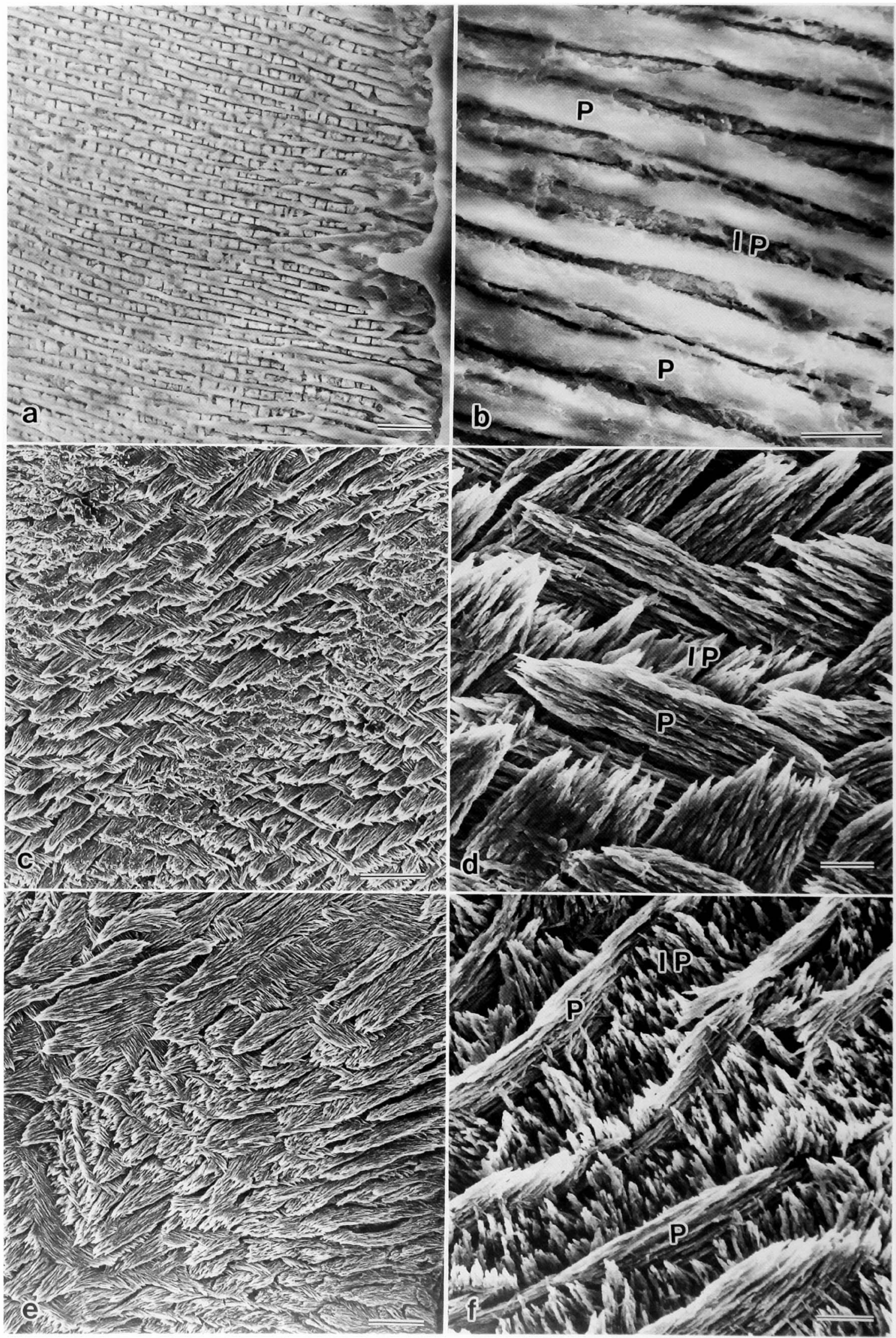

